\title{
A HYDRATED OXIDE OF CHROMIUM AS A PSEUDOMORPH AFTER ESKOLAITE, OUTOKUMPU, FINLAND
}

\author{
Yrjö Vuorelainen and T. A. HäKLI \\ Outokumpu Company, Outokumpu, Finland \\ and \\ M. Kataja \\ State Computer Centre, Helsinki, Finland
}

ABSTRACT

A new chromium mineral, hydrated oxide of chromium, has been identified as a pseudomorph after eskolaite, $\mathrm{C}_{2} \mathrm{O}_{3}$ in the Outokumpu orebody. Electron microprobe analyses suggest the formula as $2\left(\mathrm{Cr}_{1.77} \mathrm{~V}_{0.16} \mathrm{Al}_{0.04} \mathrm{Fe}_{0.03} \mathrm{O}_{3} .3\left(\mathrm{H}_{2} \mathrm{O}\right)\right.$ The mineral is orthorhombic, $\mathbf{a}_{\mathbf{0}}=5.918 \AA, \mathbf{b}_{0}=8.610 \AA, \mathbf{c}_{\mathbf{0}}=9.727 \AA, \mathbf{Z}=4, \mathbf{V}=495 \AA^{3}$; and $\mathbf{D}$ calc $=4.81 \mathrm{~g} / \mathrm{cm}^{3}$;.

\section{Introduction}

In 1943 a hydrated oxide of chromium was found by S. V. Burr in the gravel of the Merume river, British Guiana. The mineral was reported by S. Bracewell (1946) under the name merumite. According to him the mineral contains $75 \%$ $\mathrm{Cr}_{2} \mathrm{O}_{3}, 7-8 \% \mathrm{Al}, 7-8 \% \mathrm{H}_{2} \mathrm{O}, 1-5 \% \mathrm{Si}$, $\mathrm{Fe}$ and $\mathrm{Ti}$, and about $0.2 \% \mathrm{~V}$. In connection with the eskolaite studies carried out during the years 1956 and 1957 it was found out that the merumite of Bracewell was actually an aggregate of several mineral species of which eskolaite predominated. This observation was reported by C. Milton and E.C.T. Chao (1958) at the same time as Kouvo and Vuorelainen (1958) published their paper dealing with eskolaite.

In literature merumite is mentioned briefly and with certain reservations as being a waterbearing chromium oxide. In addition to $\mathrm{X}$-ray powder data, Berry and Thompson (1962) gave a formula of $\mathrm{Cr}_{2} \mathrm{O}_{3} \cdot \mathrm{Al}_{2} \mathrm{O}_{3} \cdot \mathrm{H}_{2} \mathrm{O}_{0}$ for the merumite. However, according to them the material was "unsuitable for single-crystal studies» and thus obviously not very pure.

In connection with the study on eskolaite in the Outokumpu deposit, some alteration products of eskolaite were encountered. It has been established that one of them has an X-ray powder pattern similar to that given by Berry and Thompson for merumite. This mineral is the subject of the present study.

\section{Occurrence}

Hydrated oxide of chromium has been encountered in sulphide-rich apophyses attached to the Outokumpu orebody (Vähätalo, 1953). The apophyses occur in skarn-bearing quartzite as cross-cutting dykes produced by strong tectonic movements. Besides sulphides the dykes contain 


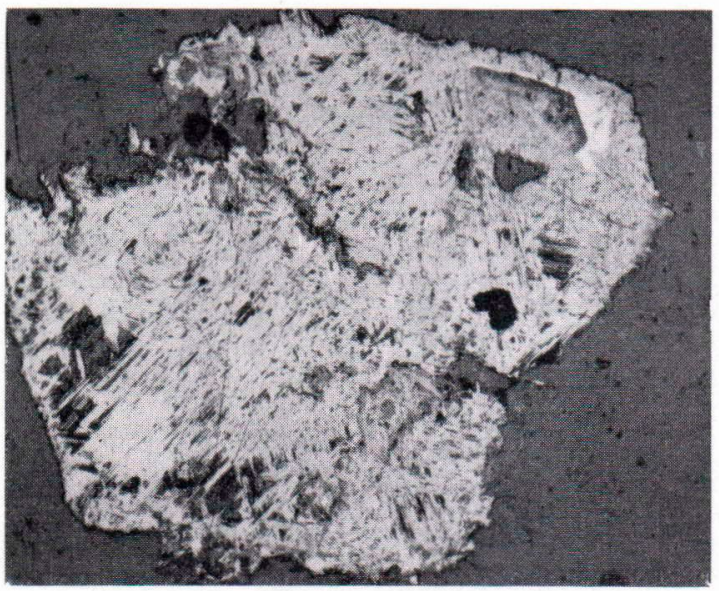

Fig. 1. An eskolaite crystal almost completely replaced by a hydrated oxide of chromium. The latter has grown as fibrous crystals along the (001) plane of eskolaite with the major morphological axis perpendicular to the prims faces. Magnification $100 \mathrm{x}$.

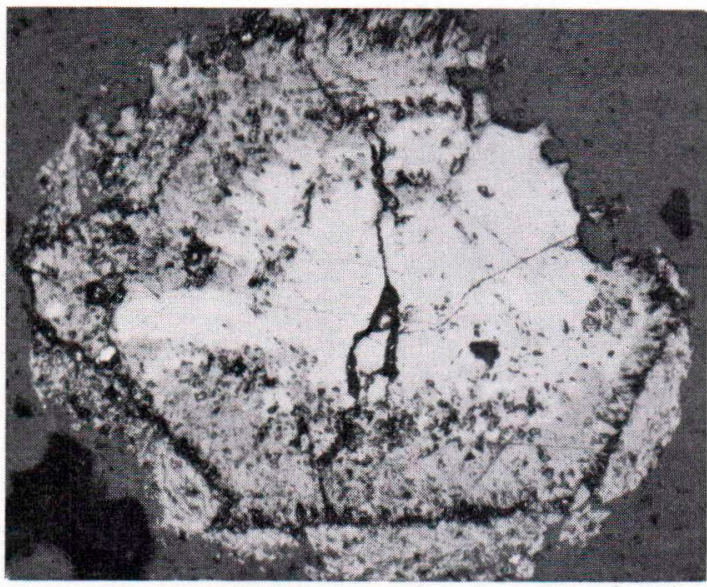

Fig. 2. Hydrated oxide of chromium replacing eskolaite. Note a dark graphite rim marking the original surface of the eskolaite crystal. Magnification $100 \mathrm{x}$.

abundant quartz and carbonate. Pyrrhotite and chalcopyrite are the major sulphides as is a coarse-grained cobalt-bearing pentlandite $(8 \%$ Co) (Kouvo et al., 1959). Several oxide minerals have also been observed in the veins. Mention may be made of eskolaite, zincian chromite (Thayer et al., 1964), rutile, uranite, nolanite (Long et al., 1963) and corundum. The latter has been met with locally as microscopic, well- formed transparent ruby crystals. The veins also contain moderate amounts of titanite and occasionally euhedral zircon. The uraninite grains are enveloped by amorphous carbon. In places, fine-grained graphite occurs as multi-form aggregates and stringers in the veins. Most of the eskolaite crystals encountered in the apophyses are euhedral, occasionally exceeding $1 \mathrm{~cm}$ in length. No alteration has been observed in the large crystals, whereas the crystals less than $1 \mathrm{~mm}$ in length frequently contain products of alteration. The most common of them is a hydrated oxide of chromium.

The fibrous mineral replaces eskolaite in such a way that the major morphological axis is on the (001) plane parallel to the prism faces (Fig. 1). In general, the pseudomorphs also contain eskolaite relics. A thin graphite film can frequently be observed on the crystal faces of the pseudomorphs (Fig. 2). Occasionally, secondary fuchsite has been formed on the surface of the crystals. The alteration can mainly be attributed to the micro cracks which almost invariably touch or cut the altered crystals.

\section{Physical and optical properties}

The colour of the hydrated oxide of chromium varies from golden brown to greenish brown. The mineral has a strong luster and the streak is greenish brown in colour. The crystals show a fibrous habit. They are small in size $(0.05 \mathrm{~mm} \times$ $0.2 \mathrm{~mm}$ ) and seem to be tetragonal or slightly rhombic in shape greatly resembling rutile crystals.

The calculated density of the mineral is 4.81 $\mathrm{g} / \mathrm{cm}^{3}$. The absorption is strong, rendering the mineral almost opaque in transmitted light. In reflected light, it is grey in colour with a slight hue of olive green. No pleochroism can be observed and the anisotropism is very weak.

Strong red and yellowish brown internal reflections hamper the observation on anisotropism. The polishing hardness of the mineral 
TABLE 1 .

Chemical composition of a hydrated oxide of chromium, Outokumpu. Electron probe analyses. $25 \mathrm{kV}, 0.05 \mu A$, LiF and mica crystals.

\begin{tabular}{|c|c|c|c|c|c|c|c|c|}
\hline & I & II & III & IV & V & VI & VII & (Mean) \\
\hline 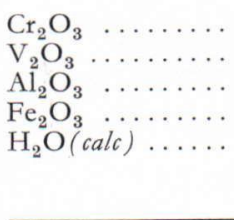 & $\begin{array}{r}75.7 \\
7.3 \\
0.60 \\
1.26 \\
15.14\end{array}$ & $\begin{array}{r}74.0 \\
5.73 \\
1.86 \\
0.65 \\
17.76\end{array}$ & $\begin{array}{r}76.0 \\
6.52 \\
0.77 \\
1.84 \\
14.87\end{array}$ & $\begin{array}{r}74.5 \\
11.9 \\
0.18 \\
0.60 \\
12.82\end{array}$ & $\begin{array}{r}79.0 \\
7.10 \\
0.66 \\
1.33 \\
11.91\end{array}$ & $\begin{array}{r}74.4 \\
5.58 \\
1.57 \\
2.16 \\
16.29\end{array}$ & $\begin{array}{r}76.7 \\
3.34 \\
1.59 \\
2.46 \\
15.92\end{array}$ & $\begin{array}{l}75.76 \\
6.78 \\
1.03 \\
1.47 \\
14.96 \\
2\left(\mathrm{Cr}_{1.77} \mathrm{~V}_{0.16} \mathrm{Al}_{0.04} \mathrm{Fe} 0.03 \mathrm{O}_{3}\right) . \\
3\left(\mathrm{H}_{2} \mathrm{O}\right)-2\left(\mathrm{Cr}_{2} \mathrm{O}_{3}\right) \cdot 3\left(\mathrm{H}_{2} \mathrm{O}\right)\end{array}$ \\
\hline
\end{tabular}

is relatively high, probably of the same order of magnitude as that of hematite. No reliable microhardness values have been obtained due to the fibrous habit of the mineral.

The large pseudomorphs take an easy polish. However, in general, the habit of the mineral and the fact that during the polishing process the crystals tend to loosen easily, renders polishing difficult. The reflectivity of the mineral is considerably lower than that of eskolaite. Measurements carried out in air with a Leitz microphotometer gave the following reflectivities: green $14.9 \%$ and red $13.1 \%$.

The mineral shows a negative reaction to the standard reagents and acids including a mixture of nitric and hydrochloric acids.

\section{Chemical coposition}

The X-ray fluorescence analyses carried out at the primary stage of the study revealed the mineral to be an oxide of chromium containing from $70 \%$ to $80 \% \mathrm{Cr}_{2} \mathrm{O}_{3}$, about $5 \% \mathrm{~V}_{2} \mathrm{O}_{3}$ and minor $\mathrm{Fe}$. No aluminium was detected. Chemically analysed eskolaite was used as the standard. Since the amount of recovered mineral barely totalled $100 \mathrm{mg}$ and since the purity of the material was too inferior for chemical analysis, the composition of the mineral was determied by means of electron microprobe analyses. The results of these analyses are listed in Table 1.
The abundance of water was determined by igniting a hand-picked sample whose eskolaite content was estimated by modal analysis and $\mathrm{X}$-ray powder pattern. The sample was weighed with a micro balance. The ignition loss of the hydrated oxide of chromium was found to be $14.4 \%$. On account of the ignition the mineral altered into eskolaite. On the basis of the analyses the composition of the mineral can be expressed as $2\left(\mathrm{Cr}_{2} \mathrm{O}_{3}\right) \cdot 3\left(\mathrm{H}_{2} \mathrm{O}\right)$. A part of the $\mathrm{Cr}_{2} \mathrm{O}_{3}$ is replaced diadochically by variable amounts of $\mathrm{V}_{2} \mathrm{O}_{3}, \mathrm{Fe}_{2} \mathrm{O}_{3}$ and $\mathrm{Al}_{2} \mathrm{O}_{3}$, depending on the composition of the eskolaite.

\section{Chrystallography}

Powder patterns were prepared by using filtered copper and iron radiations. The data for the interplanar spacings were calibrated with an internal silicon standard. The diffraction data are listed in Table 2, column 2, together with those of merumite reported by Berry and Thompson (1962).

The first attempt to index the reflections was based on a computer program developed by one of us (M.K.) at the State Computer Centre. The program was written in Algol for an Elliot 503 computer (Kataja, 1965). It finds a unit-cell a* whose q-values approach the observed qvalues as closely as possible, i.e.

$$
\mid \text { Qobs - Qcalc } \mid<\varepsilon
$$


TABLE 2 .

X-ray powder data (1) for merumite (B \& $\mathrm{T}$ 238) British Guiana and (2) a hydrated oxide of chromium, Outokumpu, Finland.

\begin{tabular}{|c|c|c|c|c|c|c|c|}
\hline I & $\mathrm{d}$ (meas.) & & k 1 & I & $\mathrm{d}(\mathrm{obs}) \AA$ & $\mathrm{d}(\mathrm{calc}) \AA$ & \\
\hline 10 & 3.23 & & 22 & 10 & 3.225 & 3.224 & Orthorhombic \\
\hline 2 & 2.53 & & 0 & 2 & 2.525 & 2.528 & $a_{o}=5.918 \AA$ \\
\hline 8 & 2.44 & & 0 & 8 & 2.435 & 2.432 & $b_{o}=8.610 \AA$ \\
\hline 2 & 2.18 & & 2 & 3 & 2.180 & 2.180 & $c_{0}=9.727 \AA$ \\
\hline 1 & 2.12 & & 2 & 1 & 2.115 & 2.117 & $Z=4$ \\
\hline 6 & 1.722 & 2 & 2 & 4 & 1.724 & 1.722 & $\mathrm{~V}=495.7 \AA^{3}$ \\
\hline 7 & 1.639 & 2 & 4 & 6 & 1.640 & 1.639 & $\mathrm{D}$ calc $=4.81 \mathrm{~g} / \mathrm{cm}^{3}$ \\
\hline 2 & 1.610 & 0 & 4 & 2 & 1.610 & 1.612 & \\
\hline 2 & 1.519 & 0 & 2 & 1 & 1.520 & 1.517 & \\
\hline 1 & 1.475 & 4 & 0 & 1 & 1.480 & 1.480 & \\
\hline 3 & 1.421 & 2 & 0 & 3 & 1.422 & 1. 422 & \\
\hline 1 & 1.382 & 0 & 6 & 1 & 1.376 & 1.376 & \\
\hline 2 & 1.342 & 4 & 2 & 2 & 1.344 & 1.345 & \\
\hline 1 & 1.141 & 2 & 6 & 1 & 1.141 & 1.140 & \\
\hline 2 & 1.090 & 4 & 4 & 2 & 1.090 & 1.090 & \\
\hline 1 & 1.058 & 0 & 48 & 1 & 1.058 & 1.059 & \\
\hline
\end{tabular}

On account of the mathematical model employed by the program, the final solution is not necessarily correct. Consequently, only a solution compatible with the density, compositional and single-crystal data can be accepted. Related computer programs have been described by Haendler and Cooney (1963) as well as Liedl and Vorres (1964). In Finland, Dr. Hyvärinen (1964) has applied computer technique to the determination of crystal lattice from the X-ray powder pattern.

The computer program suggested an orthorhombic symmetry for the British Guiana merumite with $a_{0}=2.951 \AA, b_{0}=4.314 \AA, c_{0}=$ $4.862 \AA$ and $V=61.88 \AA^{3}$.

The computation based on the X-ray powder data of the hydrated chromium oxide from Outokumpu also gave an orthorhombic solution with $a_{0}=2.959 \AA, b_{0}=4.305 \AA, c_{0}=4.864 \AA$ and $V=61.96 \AA^{3}$.

The Weissenberg and precession photographs prepared by Mr. Esko Saari, Ph. lic., confirmed the orthorhombic symmetry for the mineral. However, the cell-edges turned out to be twice as long as those suggested by the computer program (Table 3).

Table 3. The cell edges of the hydrated oxide of chromium from Outokumpu, Finland

precession phot.

Weissenberg phot.

$a_{o}=5.96 \AA$

$b_{0}=8.79 \AA$

$a_{0}=6.01 \AA$

$b_{0}=8.93 \AA$

$c_{0}=9.52 \AA$

$c_{0}=9.81 \AA$

The discrepancy between the unit cell dimensions obtained from the precession and Weissenberg photographs and those suggested by the computer program is apparently due to the fact that for the mineral $h, k$ and $l$ are all even. Under these circumstances the program, on account of its mathematical model, computes a unit cell whose edges are only half the length of the true edges.

Acknowledgements - The authors express their gratitude to the Outokumpu Company for permission to publish this paper. Professor Th. G. Sahama and Mr. Esko Saari, $\mathrm{Ph}$. lic., offered valuable aid by preparing the Weissenberg and precession photographs. Mr. Ossi Näykki, $\mathrm{Ph}$. lic., kindly determined the reflectivity of the mineral. To all these gentlemen the authors record their appreciation. 


\section{REFERENCES}

Berry and Thompson (1962) X-ray powder data for ore minerals. Geol. Soc. of Amer.

BracewelL, S. (1946) The geology and mineral resources of British Guiana. Handbook of natural resources of British Guiana, Georgetown, Sec. 4, p. 18-40. (1948) Mineralogical Abstracts 10, p. 292.

Haendler, H. M. and Cooney, W. A. (1963). Computer determination of unit cell from powder diffraction data. Acta Cryst. Vol. 16, pp. 1243-1248.

Hyvärinen, LASSE (1964). Determination of crystal lattice from X-ray powder pattern. Personal communication. KatajA, MAтtr (1965) Kidehilan ratkaisu röntgendiffraktiokuvasta. Diplomityö, TKK, Helsinki.

Kouvo, O. and Vuorelainen, Y. (1958). Eskolaite, a new chromium mineral. Am. Mineral., 43, 1098.

Kouvo, O., Huhma, M. and Vuorelainen, Y. (1959) A natural cobalt analogue of pentlandite. Am. Mineral. $44,897$.
LiedL, G. L. and Vorres, K. S. (1964) The use of computers in indexing $\mathrm{X}$-ray powder patterns. Computer Applications in Metallurgical Engineering, Ohio.

Long, J. V. P., Vuorelainen, Y. and Kouvo, O. (1963) Karelianite, a new vanadium mineral. Am. Mineral., 48, 33.

Milton, C. and Chao, E. C. T. (1958) Eskolaite, $\mathrm{Cr}_{2} \mathrm{O}_{3}$ in "merumite» from British Guiana. Am. Mineral., 43, 1203.

Thayer, T. P., Milton, Ch., Dinnin, J. \& Rose jr., H. (1964). Zincian chromite from Outokumpu, Finland. Am. Mineral., 49, 1178.

Vähätalo, Veikкo, O. (1953) On the geology of the Outokumpu ore deposit in Finland. Bull. Comm. géol. Finlande, 164.

Manuscript received, March 23, 1968. 